\title{
Self: Calling, Agency, and Transformation
}

\begin{abstract}
So, I arrived here in Israel on September the 11th 2002, one year anniversary of the Twin Towers. Stepped off the airplane and I knew that I knew that I knew that I'd made the right decision. I felt like I was home. I can't explain it, but there was a connection. It was like, it was almost in my spiritual DNA since childbirth that I was supposed to be here for however long, whether it was two years I'm here or whether for my, the rest of my life. But it was like that my destiny came into focus that day ... a page had turned in my life.
\end{abstract}

ЈАСОВ, 2012

"Nothing is by happenstance in the kingdom of God," Jacob tells me over an espresso in a café on buzzing Emek Refa'im Street in West Jerusalem. It is my third round of field work in the city and Jacob and I have decided to meet up and talk about what has been happening since last we met. We are chatting away about most everything that comes to mind: our respective jobs-mine at the university and his at a Christian ministry in Jerusalem - movies we have seen, last winter's snowfall in Jerusalem, churches, theologies, and God. Jacob does most of the talking while I listen, shooting in a question or two every now and then or when I get particularly curious about something, such as the limited possibilities for chance and coincidence in the kingdom of God. Jacob's remark stays with me during fieldwork and even after I have left Jerusalem: maybe because it seems to capture an important aspect of Evangelical culture; maybe because I recognize the sense of mild pre-determination that it conveys to me as a meaningful religious practice.

In Evangelical Christianity every individual life has a telos, a specific purpose which can be brought to realization if one chooses to listen when God beckons. "No happenstance" implies a view of reality that is ripe with intention, a sense that whatever happens, it will have meaning, something that can be interpreted, deciphered, understood. This feature of Evangelical culture is visible not only in Evangelical life stories and conversion narratives but also in Evangelical theology more broadly. Often, but not always, communities, 
states, and peoples also have an interpretable purpose in God's plan, and even non-human events like natural disasters or other phenomena that secular observers generally consider to be beyond direct human control can, for Evangelicals, be decoded. One consequence of such a theology is the active search for God's hand in history, in contemporary political, social, or religious developments, and maybe most of all, in one's own life. God's activity can be interpreted through attentiveness to one's environment coupled with theological conversations, Bible readings, and prayer. Tanya M. Luhrmann has argued that by honing your perception and directing it towards God, you learn to "hear God" and to understand the plan that He has for your life (2004, 2012). In such a linguistic context, life stories are much more than simple reproductions of past events, or even ways of making sense of individual lives. Rather, life stories in Evangelical settings are a medium through which God's plans for one's life, and ultimately God's character, come to be - at least partly — known. Through life stories, a relationship with God can be cultivated.

For Jacob, as for most Evangelicals whom I interviewed in Jerusalem, the journey to Israel is most directly understood as a response to a calling that God has placed in his heart. For some volunteers this calling has been quite explicit, for others it took considerable time and energy to decipher. Some people had "seeds planted" early in their lives but it took time-and sometimes cultivation-for the seeds to grow and blossom. For others the calling did not come until much later, and received quite immediate response. Callings also come in many different forms: as an indistinct longing for Israel; through prophetic words or individual Bible readings; in sermons by elders or pastors; or even through material objects such as TV or the radio. A general pattern, however, is that life stories are almost always recounted in ways that significantly emphasize the involvement of the divine in individual lives. The meandering journeys towards Israel are generally not understood as a result of individual choice, or the agency of the narrator. Rather, God has called the volunteers to Israel, and they have responded, sometimes even without knowing—or being able to explain — why.

The calling narratives are often placed in a broader narrative framework in which the individual's "walk with God" is the central theme: the continuous movement of the self towards increasing religious conviction (Coleman 2003). A central aspect of these "walks" in the context of Jerusalem Evangelicalism is the transformative moments in which the volunteers come to realize the spiritual significance of the State and people of Israel; in other words, the realization of Israel's place in God's plan is closely linked to the process of self-transformation. This chapter will explore the narrative construction of these coming-to-Israel stories and place them in 
relation to academic conversations about narrative identity, agency, and self-transformation (Bielo 2004, Harding 1987, 2000, Miyazaki 2000, Stromberg 1993). The first part focuses on the relationship between a divine calling and individual agency, suggesting that a central concern of these calling narratives is the temporary suspension of the protagonist's agency: a narrative operation which produces agency as a dialectical process rather than as a neatly demarcated site for intention, will, and desire. The second part of the chapter discusses how the realization of Israel's spiritual significance is articulated as a type of conversion narrative in which transformation of the religious self is closely related to increasing commitment to Israel as a religious symbol.

\section{Narratives, Performance, and Transformation}

As mentioned in Chapter One, much anthropological writing has been dedicated to the topic of Evangelical language use and the ways that language ideology and discursive practices shape Evangelical experiences of faith, agency, identity, and transformation (Bialecki and Hoenes del Pinal 2011). In some accounts, language has also been understood as the central medium of Evangelical conversion processes (Harding 1987, 2000, Stromberg 1993). From Susan F. Harding's perspective, conversion equals the process of learning a new language and being able to articulate experiences in the language of faith. Listening, Harding writes, is "coming under conviction", but it is through "speaking" that one becomes saved.

Once you are saved, the Holy Spirit assumes your voice, speaks through you, and begins to reword your life. Listening to the gospel enables you to experience belief, as it were, vicariously. But generative belief, belief that indisputably transfigures you and your reality, belief that becomes you, comes only through speech. Among fundamentalist Baptists, speaking is believing.

HARDING 1987, 179

Other anthropologists, notably Tanya M. Luhrmann, have argued that an exclusive focus on language might risk the elision of other important aspects of contemporary Evangelical experiences of God, such as cognition and bodily experiences (2004). In response to Harding, Luhrmann comments that although the convert's new linguistic/cognitive knowledge is certainly an important aspect of the religious transformation process 
it is not sufficient. For these converts, in these new and intensely experiential US evangelisms, God becomes an intimate relationship-a buddy, a confidant, the ideal boyfriend. It is not mere words that make him so but learnt techniques of identifying the presence of God through the body's responses-particularly in the absorbed state we call "trance"and learned techniques that frame that responsiveness into the experience of close relationships.

LUHRMANN 2OO4, 519

In part, I believe this critique reflects the cultural differences between Harding's and Luhrmann's field sites (Jerry Falwell-styled fundamentalism and contemporary Vineyard Evangelicalism respectively) and the relative emphasis of language and charisma within these two types of Evangelical religiosity, but I also think Luhrmann is right in pointing out that even though language is an important part of the transformation process, religious change is seldom exclusively dependent on linguistic factors. My main focus here lies on how transformation happens within language; however, as we will see in more detail in the next chapter, transformation is seldom phrased in contrast to bodily or material experiences among the volunteers, as the physical encounter with place is also a highly important factor in the movement of the religious self.

The coming-to-Israel stories are not conversion stories in a traditional sense, yet they are similar in several ways to the narratives discussed by, for instance, Peter Stromberg and Susan Harding: they are plotted as stories of religious transformation; they cultivate a dialectical relationship between human and divine intentionality; and they employ Bible-based language as an important part of the transformation process. Since the coming-to-Israel stories share these general characteristics with the conversion narratives my analysis draws upon Peter Stromberg's important study of language and self-transformation (1993) in which, inspired by Roy Rappaport (1977), he argued that rather than approaching the conversion stories of Evangelicals merely as representations of the past, they need to be understood as ritual events in themselves (Stromberg 1993, 3, 11-12). Understanding the stories as rituals goes beyond the claim that witnessing and the telling of life stories are common practices in ritual contexts in Evangelical circles. For Stromberg, it primarily means that the stories, like other types of rituals, are performances that seek to effect exchanges between the transcendental and the mundane at the moment they are told. Thus, rather than being a spoken representation of an original conversion event, the performance of 
conversion stories, Stromberg argues, is fundamental to the efficacy of the conversion itself. ${ }^{1}$

Stromberg describes how storytellers re-enact emotional conflicts-in fact, the very same emotional conflicts that are narrated as the reason for the conversions in the first place-and then resolve them by reframing them in the language of Evangelical Christianity. It is this move from what he calls "embodied aims" (the non-articulable) to articulated intentions that produces a sense of self-transformation because it brings more of the "subject's experience into the realm of self" (1993, 29). It is a move from non-sense to sense, from meaninglessness to articulable meaning. Moreover, since this new language enables the expression of what was previously non-articulable, the transformation of the self is coupled with a strengthened commitment to the new language system and its "canonical" symbols. This dual function of the conversion narrative-self-transformation and commitment-is important since it brings the meaning of symbols, and the process by which they receive a personal meaning, into close connection with each other. As Talal Asad has argued, the meanings of religious symbols cannot be isolated from the social and psychological processes in which they are used and produced (1993, 53). Thus, analyses of any particular symbol and the process by which this symbol comes to have a personal meaning for the believer are analytic tasks that need to be undertaken simultaneously. In Stromberg's theory, commitment to the symbols of the new system is strengthened through the very same process as that by which these symbols come to have personal meaning.

I take a similar approach to the calling narratives discussed here: the narrative construction of Israel as a religiously significant symbol and the volunteers' adoption of this symbol as part of religious transformation are understood as simultaneously occurring processes. Life narratives are speech acts that seek to effect changes at the moment that they are being told. By telling their comingto-Israel narratives in relation to two traditional Christian genres - the calling and the conversion narratives - the volunteers are inscribing not only their own lives and work, but also Israel, with other-worldly meaning. In other words, the sense of self-transformation to which the physical and intellectual encounter with Israel gives rise is closely related to the production of these narratives.

1 I do think this point is well-illustrated by Stromberg, but I would add that even if the recounting of conversion narratives may be the kind of ritual performances that Stromberg describes, they do not necessarily follow this pattern. Or at the very least, these characteristics of ritual are exhibited to varying extents. 


\section{The Calling}

Calling narratives, of course, have a long history in Christian traditions and a wide circulation and appeal that extends beyond Evangelical spheres. Like many other Christian ideas, the notion of a calling has also escaped its original theological context and can be said to permeate Western culture more broadly (Bellah et al. 1985, Davidson and Caddell 1994, Scott 2002, Weber 2001). ${ }^{2}$ In Evangelicalism, a calling is central to understanding one's life and work. For instance, in a recent study on Evangelical exchange students (2013), Roman R. Williams has argued that irrespective of field of study, the idea of a calling is the primary mode of framing careers and futures among Evangelical students. These narratives, he argues, can be construed as carriers of cultural values about how the world works, what is plausible, and what kinds of agency are possible $(2013,255)$. Furthermore, he argues that calling narratives offer "a compelling way to interpret the past, navigate everyday life in the present, and pursue a meaningful future" $(2013,254)$. Through these narratives this-worldly work or studies become "infused with other-worldly meaning" (2013, 264).

Considering the prominence of calling narratives in Christian tradition, and in Western culture more broadly, I perhaps should not have been surprised that the life stories of the Evangelical volunteers in Jerusalem came in the form they did, yet I was; the extent to which accounts of being called to Israel seemed to be the canonized story of the context, the absence of explicitly political motives in the narratives, and the framing of the life stories more as individual spiritual journeys than dutiful labor for the "Apple of God's eye" puzzled me. The pre-conceptions that I had of the volunteers prior to field work came largely from scholarly works on "Christian Zionism" which, as noted earlier, have prioritized top-down approaches, and construed the phenomenon as a political expression of conservative prophecy beliefs. Listening to the stories of the volunteers offered a very different perspective on why Christians from different parts of the world choose to invest time and money in supporting the State of Israel. In their accounts, the personal relationship with God moved

2 In The Protestant Ethic and the Spirit of Capitalism (2001 [1930]) Max Weber argued that the heritage of Luther and Calvin - what he called "worldly asceticism" - was "one of the fundamental elements of the spirit of modern capitalism". According to Weber, it was precisely the idea of the calling that served as the basis for modern economic conduct. Even though work in modern societies, along with much else, became "disenchanted" (Weber 2001, see also: Jenkins 200o, Williams 2013), or lost its spiritual dimension, more recent sociological studies have shown that the notion of a calling seems to have remained central to understanding work and social behavior in the West. 
from the backstage which it has often occupied in previous accounts of Christian Zionism.

Ruth is in her forties. She is a warm and humorous, middle-aged American woman with a university degree in the social sciences who has been in Israel for the past twenty years. She works in the aid division of a Christian ministry in Jerusalem, and consequently has more contact with both Israelis and Palestinians than most other volunteers. She speaks Hebrew-which is necessary for her work - and has also started to learn Arabic. Through her work and her long experience of Israel she has a profound knowledge of the local environment and is comfortable discussing even the more sensitive issues concerning politics and the various difficulties that she has encountered in Israel. In this she is not very typical among the volunteers. She is more typical, however, in how she narrates her journey to Israel and the role played by God in that journey. Her route was a long and winding one but, the way she tells it, the seed was sown when, as a child, she became interested in movies and books about the Holocaust. It is noteworthy that Ruth chooses to start her story not with reference to theologies of Israel, with Bible prophecy, or a particular religious experience, but with popular cultural productions such as The Sound of Music and The Hiding Place. ${ }^{3}$ In terms of narrative identity, this beginning emphasizes Christian altruistic ideals and universal humanist values rather than the particularity of biblical prophecy. The fascination with the Holocaust- "the books and the movies" - and the theme of wanting to help, support, and comfort the Jewish people runs like a leitmotif throughout Ruth's narrative. Apart from this "side interest" in the Holocaust, though, Israel and the Jewish people were not a very salient part of her Christian childhood. Her family was a "very devout Christian family" and "strong in reading the Word". They were part of a tight-knit Christian community but Israel-centered theologies were not a part of that as far as she can recall.

3 The Hiding Place (1971) is an Evangelical classic written by Corrie Ten Boom together with John and Elizabeth Sherrill. The book describes the Dutch Reformed Ten Boom family who rescued Jews in Holland during the Second World War. It portrays biblically informed pietism as antithetical to Nazi Germany and draws upon Pietist theologies that understood the Jews as God's chosen people "destined to regain their role as God's first nation" (Ariel 2014, 214). According to Yaakov Ariel, the book's narrative and its portrayal of the role of "true Christian believers" during the Holocaust has occupied a central place in Evangelical understandings of the relationship between Christianity and the Holocaust. Former ICEJ spokesperson Jan Willem van der Hoeven, for instance, also ascribes to The Hiding Place a central location in his own motivations for starting the ICEJ ("The Life in a Day of Jan Willem Van Der Hoeven", Israel scene, 1985, Caspari Center, Media Clippings Nov 85-Dec 85). 
Upon leaving home for college, and missing the intimacy of her childhood community, Ruth wants to find a new Christian setting in which to take part. This takes some time. She tries, among other places, an Assemblies of God congregation but nothing feels completely right until the moment when she is "randomly" invited into a Messianic community. This is her first personal contact with Judaism. ${ }^{4}$ Before this introduction to Messianic Judaism, she has known nothing of the Jewish holidays, she has had no Jewish friends and she has not given Judaism much thought, except for what she calls her "side interest" in the history of the Holocaust. Given this, it comes as a complete surprise to her when she feels "immediately and completely at home" in this community. Yet this feeling of belonging is puzzling; "Why do I feel at home?" she wonders. During the two years she spends in the Messianic community her prior interest in the Holocaust becomes personal on an entirely different level when she begins to understand the role played by Christianity in paving the way for the genocide of the Jews and other minorities during wwII. And it is here, while listening to a Rabbi explaining the history of Christian anti-Semitism, that she is called to Israel for the first time:

And I'm just horrified as I'm learning about all the ways in which the Church has been anti-Semitic and, and it was-I don't know if you believe in God still talking to people today? - but I didn't hear any audible voice, there was no, you know, whatever. I just knew that I was supposed to come here [to Israel] and love this people.

This is the first time she experiences a calling to Israel, but this time it does not stick. Travelling to Israel, she says, felt like "a crazy idea".

There are rational reasons for shrugging the experience off: she does not have any finances for the trip and she has no idea what she would do in Israel if she went. Consequently, she keeps the calling to herself, and does not tell anyone about it. Instead, she says, "[I] shoved that whole bad idea down somewhere in the far recesses of my mind." Sometime later, however, while listening to another speaker in the same congregation, it happens again, "like

4 Several academic studies of Messianic Judaism have emphasized that it is an American-born phenomenon that has developed in close proximity to Evangelicalism. Whether this historical trajectory, the expressed belief in Jesus as the Messiah, or the unorthodox use of Jewish ritual locates Messianic Judaism outside "Judaism proper" is a question that is not discussed here. The participants in this study generally understand Messianic Judaism as an authentic form of biblical religion. For more on the relationship between Messianic Judaism and Evangelicalism see (Ariel 200o, Dulin 2013, Engberg 2012, Kaell 2015). 
an arrow ... like an arrow piercing my heart". And this time her response is different: "Wow, I don't see how it could possibly happen but, you know, and I still think it's a terrible idea, but ok, we'll see." This time Ruth tells a friend of her experience. To Ruth's surprise, the friend embraces Ruth's calling, and decides to join her in going to Israel. In a way, this friend acts as a catalyst for the stillvery-uncertain Ruth. By running around and telling other people that "Ruth and I" are going to Israel the friend makes the incipient calling public. Yet, in the end, the friend's enthusiasm seems to melt away and she drops the idea. Ruth decides to go ahead anyway and sends her application to a Christian ministry in Jerusalem: "If this is from the Lord," she thinks, "He'll make it happen."

This is a very common pattern in Evangelical calling narratives: the uncertainty of the validity of the calling before the decision; the placing of ultimate responsibility outside the narrator and in the hands of God; and the way practical things miraculously fall into place once the decision is made. For Ruth, as soon as the application is sent in, "things just started happening". Her financial difficulties are solved due to unexpected donations from friends, relatives, and members of the congregation; the uncertainty about what to do in Israel is diminished by a job offer from a Christian ministry to care for an elderly Israeli woman who has suffered a stroke. Now, much more confident in the calling, Ruth decides to go to Israel.

During her first sojourn in the country Ruth loses her "heart to Israel". But, she says, "in a weird way. Because I knew fairly early on that this was a place that I could live, but I didn't come here expecting to live here, it was weird." The strong emotional attachment that she feels towards Israel is not making sense to her; she feels it, but she cannot explain why: "I ... I would weep over this country and I still do. But it never made sense to me why [I] weep over this country." When telling me this Ruth starts to cry, and continues to do so on and off until the end of the story. At several points her voice gets choked up and she has to collect herself in order to continue. The intense emotion that her story evokes is telling in itself, but the most important analytical point for my purposes here is her emphasis that her own emotional responses do not make sense. Peter Stromberg has analyzed similar non-intentional linguistic traits (affect, pauses, shifts in intensity, sounds, strong emotion) as instances where a part of the subject that it is not possible to express within the "referential language ideology" comes to the surface. For him, an analysis of these moments reveals how storytellers re-enact the emotional conflicts that are narrated as reasons for the conversions in the first place. It is precisely the move from "embodied aims" to articulable intentions that produces a sense of self-transformation, because this brings non-articulable experience "into the realm of self" (1993, 29). Ruth is unable to "make sense" of the strong emotion 
that she describes and seems to be re-enacting it in the narrative performance. The crying over Israel did not make sense then and it does not make sense now, she says, but by employing Evangelical language she is able to phrase it as a "calling". In other words, the strong emotion can be explained as an expression of divine intentionality instead of something that originates uniquely within the human subject. The narrator's inability, or unwillingness, to make sense of her own experience opens up a narrative space in the story that can be filled with transcendent intention and agency.

Unfortunately, her first time in Israel is not entirely harmonious; the question of the troubled relationship between Christianity and Judaism that she began to ponder in the Messianic congregation now invades the realm of self by becoming a concern about her own identity. In Israel, suddenly she is "one of those blasted Christians who'd done all these horrible things". The increasing awareness of this history and the reluctance to identify with it lead her into a crisis of identity; it becomes difficult for her to identify as a Christian. This "identity crisis", as Ruth calls it, is not solved during her first stay in Israel, and even back in the States she finds herself still conflicted and lost. She feels she has been "hijacked" by Israel; she is longing to return, but she has no idea what God has planned for her. The way she narrates it, this is not a question of what she wants, but about understanding what God wants for her:

I would hold onto this promise: "Trust in the Lord with your heart and lean not on your own understanding. In all your ways acknowledge Him and He shall direct your paths." ${ }^{5}$ And all the other Scriptures that talk about how He has a plan, a very specific plan for our lives, and a calling. And so, ok, well, if that's the case, then I need to know. I need to know for sure, and not just because, "Oh, it was a nice emotional thing," [becomes emotional, sobbing]. Because there's a lot of challenge in leaving behind your family and, you know, being overseas and not seeing your nieces and nephews grow up or all those different things.

Ruth's discourse about having a "need to know" indicates what Tanya Luhrmann describes as a central problem for charismatic Christians, namely, to learn to distinguish when a "nice emotional thing" is actually God trying to tell you something (Luhrmann 2012, xxiii, 39-71). Luhrmann argues that in order to become a Renewalist Christian, to learn to hear God talking to you, it is necessary "to overcome the fundamental human awareness that our minds

5 Ruth is here paraphrasing Proverbs 3:5-6. 
are private" (40). This requires developing "a new theory of mind", a more "participatory" theory wherein the mind has "porous borders" that enable you to "experience thoughts as perceptions" (41). This is a skill that can be instilled through training, and the Vineyard congregation that she studies is understood by Luhrmann as (among other things) a training facility for Christians who want to hear God speaking to them. For Luhrmann, the fundamental strategy through which these Christians develop this new theory of mind is prayer. Ruth of course already knows that God speaks to people; her mind is already "participatory". But even charismatic Christians well-trained in the ability to hear God, as Jon Bialecki has argued, need to discern between their own thoughts and perceptions of divine origin; not all thoughts should be considered to be from God (2009, 152-153). In Ruth's narrative this discernment process is long, tortuous, and filled with anxiety, frustration, and conflicting emotion. Over the course of about a year she tries to understand her longing to return to Israel, and whether this is an authentic calling or something that originates within herself. Her primary method for doing so is through conversation and prayer. At the end of the year, the identity crisis comes to a climax when, after she has been teaching in church, she breaks down in tears and the gathered group prays over her. She returns home and has a conversation with her father about the future, and again she does not know, and again she is frustrated.

And I remember being so frustrated that I went up to my room and I, I really cried out to the Lord, you know: "You have to make it clear,"-[ chuckles] I had one of those moments where you kind of scream at God a little bit- "because this is driving me nuts. I'm, you know, I don't know what to do. I don't know whether to move forward, to stop, whatever. I don't know what's going on with my heart, why am I crying all the time? I don't understand why I feel at home. Idon't understand why I feel homesick for a place that's not home." Like all these different things that were going on with me that didn't make sense to me. ${ }^{6}$

Ruth's narrative form here is interesting; once she approaches the climax of the calling narrative more and more sections are told through "direct reported speech". ${ }^{7}$ Reported speech—the discursive embedding of other agents' words

6 Direct reported speech here and below is indicated by quotation marks and italics.

7 Conversation analysis and sociolinguistic research distinguish between different forms of reported speech, the most important being "direct" (DRS) and "indirect" (IRS). There are also various intermediate forms and variations of DRS and IRS. For my purposes here it is enough to note Ruth's frequent use of direct reported speech. (See: Cacchione 2006, Clift and Holt 2010). 
within our own discourses - is a discursive strategy that can serve many different narrative and rhetorical functions apart from simply moving a story along chronologically. It has also been analyzed as a way to express an evaluation of the events or characters of a story, to authenticate a certain event, or to appeal to authority (Parmentier 1994, Vincent and Perrin 1999). In a sense all reported speech implies a framing of words as originating outside of the context of their present utterance (Keane 1997b, 61). For my purposes here, the most important function of direct reported speech is how it can serve to dramatize an event, even to re-enact the event that is being recapitulated (Bauman 1986, Briggs 1986). As Stromberg has argued in his analysis of reported speech, the story does not only "recount" the storyteller's experience; on the level of performance it actually "recreates it" (1993, 106-107). In the quote above Ruth's usage of reported speech serves to re-enact her own conversation with God, and the emotional conflict in which she then found herself. By actualizing the past, the re-enactment also provides a narrative platform for the climax of the calling narrative.

Ruth story now flashes back to something that happened very soon after she returned to the States from her first sojourn in Israel: a male acquaintance from her church asked her where her home was. Upon seeing her struggling to find an answer, he told her: "I've just been praying for you and I feel like there's gonna come a time when you won't have two homes, and home's going to be the place that the Lord has called home for you.' " In Evangelical discourses both extracts from the Bible and dialogues with God are commonly reoccurring instances of reported speech, but here it is an unnamed man who is the speaker. About a week after Ruth's tears in church, the same man appears in the story again and tells her that when they were praying for her last week he " 'kept hearing something in [his] spirit.' " Again, Ruth is telling this in third person. The man says:

"It doesn't even make sense to me. I don't even know what it means. Maybe I heard it in a song somewhere," he says. "I didn't feel to say anything last week but now I'm thinking I should share it with you and see if it's something for you or not." And I'm thinking, "Oh Lord, what's coming?" [laughs]. And he, and he said, "I kept hearing 'Shuvi Ruth, shuvi.'Does it mean something?" [chuckles] He says: "I don't know what it is, does it mean something?"

Shuvi does mean something. For Ruth, knowing Hebrew, this makes complete sense: Shuvi is the Hebrew word for "return". In the story Ruth is told by a man who does not speak Hebrew that she ought to go back to Israel. It is the message for which she has been waiting and praying and she takes the words to heart as a direct communication from God. A week later, this third calling, or 
calling back, is reinforced by the term appearing again in an Israeli song in a dance class Ruth takes in church. Still slightly uncertain ("I'm still a little bit like, 'Yeah, but my Hebrew's not that great, so maybe, maybe, you know, maybe I'm wrong." ") Ruth asks her friend what shuvi means and the friend says, "'Return," " but, the friend adds, "it's the feminine command form of the word." Once again Ruth receives the confirmation that she has waited for. Now certain that God has called her back, she decides to return. This calling took place twenty years ago; the last two decades she has spent working in Israel.

Clift and Holt have pointed out that one of the most frequently reoccurring instances of direct reported speech takes place at the climax of a story, a point which is also illustrated in Ruth's narrative (2010, 2). In these climactic scenes the unnamed man delivers a message in a language he does not know, but which the narrator does. In a sense, the man serves as an unknowing mediator of divine intention. His ignorance is also significant since it circumscribes the possibility that the message originated with him instead of with God, as it is meant to be understood. As with Pentecostal discourses of glossolalia and Islamic traditions concerning the illiteracy of the Prophet, the ignorance of the messenger/mediator is here something that does not delimit but rather increases the power of the message as it indicates that its authenticity cannot have been distorted by the human mind. Since the mediator is ignorant, the message is framed as authentic; it is not symbolically manipulated or manufactured. In his study of spiritual mediums sociologist Robin Wooffitt has argued that the use of reported speech is a key rhetorical practice among the spiritual mediums whom he studies which serves to establish the authenticity of their claims to be able to speak with the dead (2001). Similarly, Erwin Goffman argued that reported speech can serve to "reduce personal responsibility" for the things that are being said, and noted that speakers were, for instance, more likely to use curses and taboo utterances when using reported speech than otherwise (1981, also quoted in Clift and Holt 2010, 8). There is good reason to believe that these functions of direct reported speech are also relevant in relation to Ruth's calling, which is narratively placed in the mouth of the unnamed/ unknowing man. Responsibility is reduced - though in an agentive, not a moral sense - and the sense of authenticity is increased by the fact that the man is delivering the divine calling in a language that he does not speak. Neither Ruth nor the man is the agent responsible for the calling; to say either was would not make narrative sense. The remaining option is that the calling is of divine origin, and that "'Shuvi Ruth, shuvi,' " is an authentic reflection of divine intent.

Ruth's narrative of the meandering journey that brought her to Israel in a physical as well as in a spiritual sense illustrates a trope that is endemic to the linguistic context of the volunteers in Jerusalem: that God has called them into 
service in Jerusalem. Moreover, in many of the volunteers' narratives a "calling" is seen as a necessary pre-requisite to be able to function psychologically, socially, and spiritually in a situation which is commonly understood as especially "spiritually intense", a theme which is developed further in the next chapter. I return to Ruth's story when discussing self-transformation below, but before doing so I believe it is worth taking a closer look at the relationship between human and divine agency as it is articulated in the calling narratives.

\section{"It Wasn't Our Idea"-Calling and Agency}

As already mentioned, calling narratives - as well as other types of life stories - can be understood as carriers of cultural values and beliefs about how the world works and what kinds of agency are possible in it (Williams $2013,255)$. While life stories always deal with agency to some extent, in that they are concerned with explaining the protagonists' life choices, motives, and reasons for acting, the negotiation of agency is a particularly salient theme in calling narratives. As Webb Keane (1997a) has pointed out, ideas about agency are historically and socially situated products that are, at least in part, dependent upon local beliefs and linguistic practices. Thus, the calling narratives presented here reflect more general Evangelical beliefs about how human and divine agency works, as well as evaluations about what forms of agency are preferable.

With this in mind, perhaps the most striking feature of the narratives told by the volunteers in Jerusalem is how the callings are dependent upon a temporary circumscription of human agency. This aspect is not discussed explicitly in Williams' analysis of Evangelical calling narratives. Instead he draws upon Dan P. McAdams notion of "personal myths" and, like McAdams, emphasizes narrative coherence and the harmonizing effects that calling narratives have on narrative identities (Williams 2013, 273, see also McAdams 2006). In contrast, the central scenes of the calling narratives discussed here, and their interpretations, are often constructed around a protagonist with limited control over their own lives, ridden with uncertainty, struggling to make sense of the situation in which they find themselves. Often the callings come in the form of an inchoate yet intense feeling of longing or love that is construed as a possible, but not certain, expression of divine intention. Consequently, the protagonist is obliged to explore the calling to try to understand whether the feelings are being interpreted correctly, and then to find the courage to follow the calling once the discernment process is finished. This temporary suspension of human agency is not understood as negative, but rather as a prerequisite of authenticity; a calling is not a calling if it cannot be "traced" back 
to divine intent. As Phillip, one of the older volunteers who, together with his wife, continually travels back and forth between Israel and their home country, says when explaining their sense of calling: "The best thing I'll say about this whole thing ... [is that] it wasn't our idea."

\section{Suspension of Agency}

One of the clearest examples of the ways in which human agency is circumscribed in the life stories of these volunteers comes in an interview with ayoung European woman called Hanna. She relates how she was called to Israel in a series of events starting with an indistinct feeling that "there was something about Israel" during a fast that she undertakes together with her congregation. It is a feeling that she does not think much about at first, but it keeps coming back and she eventually realizes that she has to explore it in more detail. Perhaps God is trying to tell her something? She describes herself as a logical and rational person so the natural thing to do is to explore intellectually what Israel was all about. She "started to research it", she says, as, prior to getting this feeling, she did not know much about Israel or about "the biblical promises". She goes online and discovers one of the Christian Zionist ministries and the prophetic understanding of Israel that they espouse and eventually finds herself applying to volunteer for them. When looking back at this process, and when trying to explain it to me, she finds the logic of the process slipping through her fingers.

What happened after that was a little bit difficult to explain because I'm a very kind of logical person and for me to leave my job, to leave my home, and to move to a foreign country where I don't speak the language, I know nothing about the culture, I barely knew what Judaism was-barely-I mean, nothing. It was just absolutely absurd and made no sense. So I tried to go back and think about when did I make that decision? And I can't pinpoint the time. I just found myself applying; I found myself in communication; I found myself quitting my job. ... So, that's why I feel very strongly that I was brought here. Because there's no logical explanation as to how I actually got to be here. (my emphases)

The turning points that brought Hanna to Israel do not make sense to her. In fact, in retrospect she is unable or unwilling to construe her journey to Israel as being a result of her own decisions and choices. She cannot "pinpoint the time" when she made the decision, she says, and the narrative conveys a strong sense that the "decision" is rather something that happened to her. This sense is 
further strengthened when Hanna talks about herself as passive in the process that took her to Israel; she "found" herself applying, communicating with the ministry, and quitting her job.

Peter Stromberg has described how the "referential ideology" (see also: Keane 1997a, 68o-682, Woolward 1992) that he understands as the hegemonic view of language and subjectivity in modern Western societies entails a "particular view of the subject in which meaning is tied to the subject's intention" $(1993,17)$. This view of the subject, he argues, is likely to be regarded as "common sense" in Western societies. In this common sense view of language, intentional acts are actions that "may be connected to a project in some construable way" (1993, 19); one may ask "why?" about an intentional act. In contrast, if the act is unintentional-for example, spilling a cup of coffee or slipping on a pavement - the question simply does not make sense. Or, it makes sense only as an ironic joke, not as a genuine question. Furthermore, "if a behavior can be linked to a project, it is thought to represent whatever it is in the human organism that construes projects" $(1993,19) .{ }^{8}$ The statements Hanna makes about the turning points in her trajectory sound mysterious precisely because there is an interpretative gap between the acts described and the character doing them. By emphasizing how unlikely it is that she - "a very kind of logical person" - would act in the way the protagonist in the story acts she creates a narrative gap between the narrator and the protagonist that offers a sense of confusion or mystery. The narrator says she is logical, the protagonist acts in a way no logical person would act. The scene does not make sense because the behavior of the described character is at odds with the narrator's description of the character. This might be seen as a case of what Wayne C. Booth called the "unreliable narrator" in his classic The Rhetoric of Fiction (1961): not to imply that Hanna is an unreliable or untrustworthy person, but that the rhetoric of the narration creates a gap between the narrator and the character that is being described. Unreliable narration has often been used, and often been analyzed as, an effective rhetorical tool to create humorous effects, or to emphasize perspectivism and limited knowledge (Herman, Jahn, and Ryan 2005, 623). The point for Hanna however, is not to make people laugh, but rather to emphasize the impossibility of construing the protagonist as responsible for the project of going to Israel. In this vein Hanna also suggests an answer to the confusion her

8 Stromberg here describes how "character" and "intention" work within what he calls the "referential ideology". In his view, this referential ideology is tied to certain conceptualizations about human subjectivity that reflect a simplified cognitive model, and which diverge from "actual experience" (Stromberg 1993, 17-23). 
description of the scene creates. In the last two lines in the excerpt above, she suggests that the reason that she acted the way she did was that she was "brought here". The lack of logically plausible explanations for the character's behavior points to the conclusion that the reason for that behavior is not to be found in the character, but rather in a force that is external to it. Her coming to Israel, she suggests, is not a consequence of human agency but of divine intent and human receptiveness.

Hanna's explanation as to why she is in Israel can be connected to a "project in some construable way" (Stromberg 1993, 19), but it cannot be "thought to represent whatever it is in the human organism that construes projects" (1993, 19). The answer to the why-question about the project— going to Israel—is not to be found in her character because it is not her project; it wasn't her idea. Her act is unintentional—she describes herself as passive — and yet it is possible to ask without irony why she went to Israel because in Hanna's answer the project still refers back to a character, the act is still intentional; it is only that it is not her intentions, or her character that the project references, but God's. By removing the possibility of interpreting the events that brought her to Israel as consequences of purely natural causes - to which we also have to add character and intention-Hanna increases the plausibility that it was supernatural causes that brought her there.

\section{Narrative Non-Sense Making}

Not being able to understand the motives and intentions of the protagonist might be as confusing for a listener to a story as it can be for a reader of a novel. There is good reason to believe, however, that the confusion that Hanna's narrative conveys is not the by-product of an inexperienced storyteller, or a person lacking sufficient introspection to understand and plausibly convey her own life journey. This is so because, firstly, Hanna does not at all give that impression generally throughout the interview, rather she gives a rational impression, she is highly detailed in her motivations for her political and religious views, and is very argumentative; secondly, Hanna is far from an isolated case in the material here discussed. The narrative uncertainty that she conveys regarding her own decisions and choices is also reflected in several of the other calling narratives. Consider, for example, Ruth's discourse, mentioned above, where she struggles to make sense of her strong emotional attachment to Israel. In some cases, the emphasis on God as the prime agent of the life stories even appears as one of several language games available to the storyteller. In these cases, the storytellers seem completely able to give two different accounts of their journey to Israel, one in which this-worldly motives and explanations play the primary sense-making role, and another in which god-talk and the language 
of faith is in the foreground. These storytellers can move between the different language games and adapt their story to their perception of the audience, whether internal or external, and how they want to portray themselves to that audience. These reasons suggest that-rather than approaching the circumscription of human decision-making and the different kinds of uncertainty (or things that "do not make sense") in the calling narratives as speakers' inabilities to understand life choices and emotional responses- these practices constitute part of the Evangelical tool kit for storying lives. They are cultural tropes, or what Jerome Bruner has described as a canon of possible stories (Bruner 1991a, b, 2004). By drawing upon this resource the Evangelicals narratively limit personal agency, and by implication, open up an agentive space for God.

If "sense making" is the process by which human beings give meaning to experiences, the process described above can be seen as a sort of "narrative non-sense making", a process by which narrators create ambiguity as to the meaning of the events they are talking about. While Ruth repeatedly describes her own emotional responses as "weird", Hanna alludes to her life choices as "absurd", and claims that they make "no sense". According to the Oxford Thesaurus of English, "absurd" refers to something illogical, untrue, or nonsensical: something that is inconsistent with reason or with common sense (2006, 6). In other words, within what Stromberg calls a common sense view of language, where meaning is closely tied to intention, it is not possible to ascribe any meaning to the events that Hanna and Ruth describe. They are absurd. For both Hanna and Ruth, "the meaning" of the events is remarkably opaque and interpretation is (temporarily) suspended by the narrators. This effect is part and parcel of the particular language game, or the genre, to which these life stories belong. A calling cannot be a calling unless there is miraculous intervention in the life that is being described. The calling is made rhetorically plausible by the construction of nonsensical situations. This confusion is resolved by the introduction - explicit in the case of Hanna, more subtle in the case of Ruth-of supernatural agency.

But why create non-sensical situations or temporarily suspend interpretation if the tools to find the answers are already provided? The process described here is similar to what Susan Harding alternatively calls "narrative gaps" and "interpretative gaps" in her analysis of fundamentalist—particularly Jerry Falwell's—language and politics (2000). An interpretative gap, she writes

is a silence, or an anomaly in a story that incites imagination by failing to meet expectations, a little like a clue in a murder mystery; or an odd sound at night, downstairs, near the back door; or two friends gazing at each other a bit too long and longingly to be "just friends". A miraculous 
gap or excess fails to meet worldly expectations in a way that opens up a space for supernatural action.

HARDING 2000, 86

In her case study of televangelists Harding exemplifies this practice both with the numerous inconsistencies in the biographical accounts of the evangelists and with the explicit inclusion of Jerry Falwell's moral flaws in his own biographies. The interesting question, she asks, is, "[W]hy does Falwell narrate the gaps, why does he stitch the holes in his stories to begin with?" (2000, 97). In response to this question she suggests that the narrative gaps, the silences, the excesses, and the moral oscillation in televangelists' narratives should not be treated as incidental or as mistakes, but rather as necessary for the "production of truth" amongst the listeners. Truth and faith, she argues, are produced through the harmonization of the gaps and discrepancies, because fundamentalist Baptist interpretation "rests on a poetics of faith, not on a hermeneutics of suspicion" (Harding 2000, 88). Listeners/readers of these storied gaps are invited to reconcile them, to close the gaps, and are consequently contributing to the production of faith and truth (2000, 86-104).

Narrative non-sense making could be seen as one way to "stitch" holes into stories; although not necessarily in the sense of a conscious rhetorical strategy but perhaps more as a culturally recognized way of speaking. The televangelists might be "masters of this kind of narrative instability" $(2000,86)$, but it is a practice widely employed among Evangelicals, including those outside the pulpit and the God Channel. In a disenchanted world, miraculous events need to be defended and, on a rhetorical level, narrative non-sense making supplies what is required. Even believers in miracles have to judge the evidence available that supports particular miracles, and speakers consequently have to provide what proof they have (Bialecki 2009). By de-emphasizing natural explanations, and by limiting human agency, narrative space for the involvement of the divine in individual lives is created. The calling narratives analyzed here employ this technique in order to make the transcendental origin of the callings seem plausible to the listener but also to themselves.

\section{Agency in Abeyance}

So far the analysis of agency in the calling narratives has emphasized the narrative strategies that are employed to delimit human agency in order to make space for an actively involved God. It was argued that one such strategy is the construction of narrative situations that are absurd or non-sensical if one 
rejects the possibility of supernatural agencies. ${ }^{9}$ Yet the calling narratives generally do not linger long in that confusion; rather the trajectory is one in which confusion is transformed into insight, ambivalence into certainty, and absence of agency into a clear sense of purpose and identity. A very common pattern is the one exemplified by Hanna above. For her, an initially profound, yet indeterminate and ambiguous sense of calling that she finds hard to understand gets its precise form through her own labor. Hanna says that she "started to research" the spiritual significance of Israel through communication with other Christians and searches on the internet. Similarly, many volunteers describe how, after having received the calling, they turn to the Bible and read it anew with a different perspective. In other words, personal Bible study is understood as a method for reaching comprehension of the meaning of the calling, for discerning its authenticity, and for determining its shape and form: a bit like the work performed by a sculptor when transforming a block of marble into a human shape dressed in a laurel-leaf crown and toga. Yet this spiritual labor on the part of the volunteers is often understood as needing guidance; it is God, or the Holy Spirit, that "opens up" the Scripture and lays bare the spiritual significance of Israel that was always there, hidden under the trappings of Christian theological traditions. In terms of biblical study being used as a method to make sense of an intense but as-of-yet shapeless calling, human agency returns with force. As will be explained below, however, this connection between divine and human agency is also more than a mere chronological link; it is dialectical in the sense that the latter is often narrated as logically dependent on the former. The production of meaning is dependent upon the presence of situations of meaninglessness (Engelke and Tomlinson 2006b). In order to fulfill one's calling, one often needs to learn to place one's own "agency in abeyance" (Miyazaki 2000). For some of the volunteers, like Jacob whom we met at the beginning of this chapter, this ability is severely tested. God "places Israel on his heart", but when he feels ready and willing to go, God does not let him.

Jacob is a middle-aged American man who has been a volunteer with one of the organizations in Jerusalem for about ten years. He is humorous and friendly, easy to talk to, and one of the first volunteers whom I got to know a bit better. He gives the impression of a thinker who has spent a lot of time developing

9 There are several examples in the interviews of other supernatural agencies besides God, primarily of the malicious kind (Satan and/or demons). For instance, the conflict in Israel/Palestine is generally emphasized to be of a spiritual nature, and benevolent and malicious spiritual forces are understood to influence the different actors in the conflict. However, in the calling narratives, very little attention is paid to agencies other than human and divine. 
his ideas about himself, about God, and about the world, all of which makes him a very good storyteller. In his story, Jacob describes how he "gave his life to Christ" as a teenager, had a "few good years in the Lord" but eventually suffered some events that "shattered his faith" and sent him on what he retrospectively describes as "the years that the locusts had eaten". ${ }^{10}$ These "years of the locusts" are full of tragedy, of anger, and of what Jacob calls "un-forgiveness". He describes himself as completely lost and as suffering from an inability to forgive some people who had wronged him.

And the next eight, nine years were just pure unadulterated hell as I walked away from everything I knew. And then, it's like it says in Proverbs, you know, "a dog that returns to its own vomit"; that's exactly what I did. And ... it was destroying me, even my physical appearance was changing, my mental appearance, everything. And there is a lot more to this story than what I'm saying right now, but needless to say, my life was really at an end. ${ }^{11}$

The mental, physical, and spiritual breakdown that Jacob suffers through these years is narrated as an enslaving cycle of self-destructivity. The "dog returning to its own vomit" is a metaphor of compulsion, a self-destructive pattern that he is unable to break free from on his own. Eventually, the release from "the locust years" comes in the form of a combination of divine intervention and patient Christian friends who help him break out of the negative spiral. Some years later, when Jacob returns to faith, God immediately starts to bring people into his life with connections to Israel and a "little seed" is planted, he says. Eventually, cheered on by a friend, he decides to apply for a discipleship program in Israel but when he begins to fill in the application

the Lord spoke to my heart and said, "Nope, you're not going to go this year." I'm like: "What?" I was all excited; I'm ready to go. "Nope, you're not going this year." So I tucked the application away in a drawer and continued to let the Lord work in my heart. ${ }^{12}$

10 The "years that the locusts had eaten" is an implicit reference to Joel 2:25 which reads: "I will repay you for the years that the swarming locust has eaten, the hopper, the destroyer, and the cutter, my great army, which I sent against you". It is also one of many examples of how biblical language and idioms continually bleed into Jacob's narrative and helps him make sense of his experiences.

11 The biblical reference is to Prov. 26:11: "Like a dog that returns to its vomit is a fool who reverts to his folly".

12 Like Ruth, Jacob frequently uses direct reported speech for his communication with God in these climactic scenes. 
Jacob interprets God's refusal to let him go as a sign that he is not yet ready; that there is "physical and emotional" baggage that God needs to work on before He will let Jacob go. The application process happens once a year, so during the year following the first refusal Jacob buys books about Israel, and starts to go to a Messianic congregation. When the application process restarts, God again, to Jacob's great frustration, refuses to let him go. This second time Jacob's response is more intense, he rips the application apart in anger and answers God: " Why have I got this desire in my heart, and you are not letting me go? Fine, I won't ever go then.' " This state of mind does not last, however. By the time the application process starts for the third year his anger has melted away and he decides to give it a third try, and this time God lets him go.

And then there was a series of events that happened in one day that I knew it was a confirmation that it was time for me to go to Israel.... So I submitted the application, I was accepted and ... then I sold everything I had, my car; I quit my good job that I was gonna do for the rest of my life, but I knew that I knew that I knew that I was supposed to go for nine months to Israel. ... And they said: if you leave, you can't come back. But I knew that in my heart of hearts that this was a fork in the road and I thought, "You know what, God has delivered me from so much and He's given me so much, it's up to Him what happens after those nine months; I've got to take this chance." You know, it's almost like the greater, the greater the risk, the bigger the reward ... So, I arrived here in Israel on September the 11th 2002, one year anniversary of the Twin Towers. Stepped off the airplane and I knew that I knew that I knew that I'd made the right decision. I felt like I was home. I can't explain it, but there was a connection. It was like, it was almost in my spiritual DNA since childbirth that I was supposed to be here for however long, whether it was two years I'm here or whether for my, the rest of my life. But it was like that my destiny came into focus that day ... a page had turned in my life.

The two times that Jacob is denied permission to go create an intensification in his story that eventually comes to a high point when his prior frustration is transformed into an absolute certainty that it is his purpose to go to Israel. As with Ruth's story above, these climactic scenes are narrated through the use of direct reported speech; the story moves chronologically through a reported dialogue between God and Jacob. Jacob's certainty is emphasized by the many times that he uses the form, "I knew, that I knew, that I knew"; and, as if this was not enough to underline the certainty, he adds: "I knew 
that in my heart of hearts." Finally, he elaborates on the feeling of certainty and peace when he says that coming to Israel "felt like I was home"; it was even as if it had been in his "spiritual DNA since childbirth". This was not just a trip like any other, it was not just nine months at a discipleship school in a foreign country; it was as if his "destiny came into focus", as if "a page had turned in [his] life".

The knowledge that Jacob describes is a sort of foundational knowledge, an intuitional knowledge bordering on absolute certainty or an unquestionable truth. This form of knowing among Evangelicals has been discussed in numerous anthropological studies of charismatic and Evangelical Christians (Bialecki 2008, Bielo 2004, Durbin 2012, Luhrmann 2012). In his Walking in the Spirit of Blood James S. Bielo describes this as "heart knowledge" which, he argues, serves as "the center of moral identity" (2004, 271).

The location of intent, the decider of belief, the division of right and wrong action, and the ability to understand spiritual matters combine in these discourses to define what lies in the heart: the true self. By revealing the true nature of the self, the heart emerges as the core of moral identity. The heart is where God touches you and is the conduit through which the fiber of the moral self is altered. To give your heart to God means to recognize God's sovereignty over your life and to commit to place your relationship with God before all else. Yet, for all its significance and ability, the heart is beyond a person's ability to understand.

BIELO 2004, 274

Bielo focuses on the heart as the center of moral identity but in his account the heart also serves as a site of knowledge; it is the location of "the ability to understand spiritual matters". In statements such as "I knew that I knew", and "in my heart of hearts", the heart fundamentally represents a knowledge that is beyond question, critique, and, perhaps paradoxically, comprehension. If "head knowledge" was the preferred mode of knowing in old time fundamentalist discourses about Bible interpretation, theology, and evolution (Harding 2000, 141, see also: Marsden 2006, 7), "the heart" in Jacob's and many other volunteers' stories emerges as the paradoxical center of an Evangelical, or charismatic, epistemology. ${ }^{13}$ And paradoxical it is, because the

13 The heart versus head knowledge dichotomy is not unique to the case presented here but rather a fundamental aspect of Christian revivalist discourse. Similar debates are observable in the different stages of Reformation history, for instance in Pietist polemics against Lutheran Orthodoxy. 
heart is where you receive "confirmation", the site where you know beyond question, and yet it is not logically possible to make sense of this knowledge or fully comprehend it. Narrative non-sense making and the emphasis on heart knowledge shares an epistemology that limits the possibilities of human understanding and allows Evangelicals to connect their own life to cultural tropes such as God's plan. Yet, although narrative non-sense and heart knowledge share a common epistemological frame, as narrative practices they differ from each other: whereas the former presents a locus of confusion, the reception of heart knowledge is one of profound insight. While decision-making processes and even the possibility of comprehending these processes may be narrated as instances where personal agency is in abeyance, the moments of insight are depicted as instances where it returns with force. When Jacob landed in Israel his destiny came into focus; it was, he says, as if a page had turned in his life. And a page has turned in his narrative; Jacob now knows - beyond question - that he is where he is supposed to be; in fact, he is where he was always supposed to be.

Jacob's narrative conveys a Christian subjectivity that is developed in an intimate - even indispensable - relationship to supernatural forces. Divine agency is understood to exist in a dialectical relationship with Jacob's own will(s), intention(s), and desire(s), even his very capacity to act. This is initially illustrated in the general trajectory of the narrative which moves from a situation of bondage during the "locust years" to one of meaning and purpose. When separated from faith Jacob is bound by the destructive forces in his surroundings: he is a "dog that returns to its own vomit". He suffers spiritually, mentally, and physically from the self-destructive spiral that he is unable to escape on his own. As is common in Christian conversion narratives, relief from this situation comes through divine intervention, when "the Lord started to take the chains off of" him. It is through a return to the Lord, which is preconditioned on Jacob's ability to forgive, that the things binding him release him and he is able to act once more. This rediscovered agency is then put to the test, however, when attempting to complete the application forms. At this point Jacob must place his agency in abeyance and wait for God to decide when he is ready, in spite of his calling, his sense of feeling ready, and his desire to go. In close proximity to the biblical narrative about Abraham's sacrifice of his son, Jacob has to ignore his own emotions, even his incomprehension, and recognize that God's will is sovereign.

In the social scientific study of narrative, life stories are commonly considered to reflect and shape individual identities (Bruner 2004, Gergen and Gergen 1997, Holstein and Gubrium 2000, MacIntyre 2007, McAdams 2006, McAdams, Josselson, and Lieblich 2006, Ritivoi 2008). In Jacob's life 
story not only identity but also a personal theology is reflected on, shaped, and constructed. Theology and identity formation here are closely linked. Jacob's narrative illustrates that the modern tendency to locate agency primarily in humans (Keane 1997a), and/or social structures fits poorly with Evangelical conceptions of calling, subjectivity, and identity. As Evangelicals profess belief in a God that is profoundly involved in history and the lives of individuals, agency is naturally located not only in the believers, but in the object of that belief as well. Analysis of these calling narratives has shown how this understanding of agency is embedded not only thematically, but also formally, in the linguistic practices of the volunteers. Indeed, several authors have argued for the need to pay more attention to "forms of agency that do not necessarily privilege the autonomy of human agents" (Miyazaki 2000, 31, see also: Bialecki 2014a, Keane 1997a, 1997b). As notions of agency are formed through historical and social processes, and are in part dependent on local beliefs and speech practices, it is unsurprising that religious communities might not want to claim all agency for themselves but might instead "prefer to find it in other worlds" (Keane 1997b, 66). In addressing these non-human forms of agency Miyazaki has suggested a theory about the "abeyance of agency" (2000, 31), which I have already mentioned above. He argues that religious practitioners might not share the social scientists' problems with locating agency in experientially inaccessible entities (such as spirits or God) but instead insist that "what is at issue is not so much the agency of these entities as the limits of human agency - their own or others ... their own capacity to make sense of events or even their capacity to act" (2000,32). From this perspective he continues, faith "emerges not so much as a Kierkegaardian leap of belief in something beyond comprehension but as a capacity to place one's own agency in abeyance" (2000,32). This capacity is visible in the life stories of these Christian volunteers. Seen from the perspective Miyazaki suggests, narrative non-sense making emerges less as a rhetorical strategy employed to convince a present (or internalized) audience of the validity of the calling than as a fundamental religious practice. The circumscription of individual agency represented in the calling narratives can then be seen as the very language of (Evangelical) faith.

"Abeyance", however, does not imply relinquishing agency completely or indefinitely; abeyance is a temporary state. Placing their lives in God's hands for these Evangelicals is more than a one-time event happening at the time of conversion; "to walk with God" is a religious practice that one must do, and continue to do, with increasing magnitude and sincerity throughout the life course (Coleman 2003, Luhrmann 2004, 520-521). Jacob's narrative, for example, 
continues after the excerpt with several theo-biographical accounts of his struggle to place more and more of his life into God's hands. His nine-month stay in Israel develops into a story about learning to listen, and learning to trust God completely through financial difficulties, through uncertainty about the future, and through the fear of living in Jerusalem during the Second Intifada.

Thus, learning to rely on God, for many Evangelicals, does not restrict their capacity to act or their sense of freedom, but rather increases it. All three narratives discussed here convey ideas about freedom, understanding, and agency that are dialectical in nature; in Jacob's narrative freedom is developed through practices that delimit freedom. In Hanna's story, understanding that God has called her to Israel comes through the making of narrative non-sense and the subsequent acts of researching Israel. In all cases agency is developed in a process where the temporary narrative circumscription of agency not only chronologically, but logically, precedes the sense of agency that the narratives conveys.

The capacity to place agency in abeyance is one highly prized in Evangelical communities and the calling narratives display some of the rhetorical strategies by which faith, in Miyazaki's terms, becomes narratively embedded. Like most Evangelicals, these voices simultaneously adhere to ideas about free will and the ultimate control of God over everything created, and the narration of agency reflects this paradoxical understanding of the possibilities for human action. What emerges from these narratives is a concept of agency that privileges the dialectical relationship between human and other-worldly forces rather than one dependent only upon human autonomy and self-sufficiency. This concept of agency is dialectical not only because it describes a forward movement that requires both attracting and repelling forces between opposites but, more importantly, because these opposites are integral components of each other. What I have here called narrative non-sense making is a constitutive component of Hanna's process of understanding her life journey; it is through the practice of making narrative non-sense that she makes sense of her divine calling.

\section{Self-Transformation}

So far I have argued that a central aspect of the calling stories of Ruth, Hanna, and Jacob is how narrators locate divine agency in relation to the self. As we will see in the following chapters, the resulting relationship between human and supernatural agencies is not limited to Evangelical understandings of the self, but also comes into play in the context of Evangelical 
engagements with the biblical text and with the world; in that sense the relationship can be seen as an important part of the tool box which Evangelical Christians utilize to make sense of the world and their own place in it. As Peter Stromberg has suggested, this interplay between divine and human agency in narrative performance is also closely related to the sense of self-transformation that these narratives often convey (1993, 76-100). Thus, in the final part of this chapter I return to a theme raised in the introduction: how the coming-to-Israel stories are narrated as a type of conversion narrative. On the one hand, personal transformation is a general and frequently occurring theme in the volunteers' stories of the effect that is often ascribed to trips to Israel, for instance, and to how living and working there is understood to deepen and develop personal faith. On the other, transformation is also a theme that is particularly connected to the moment when the protagonist suddenly realizes Israel's spiritual significance, a moment which is often described in a language that emphasizes suddenness, spontaneity, and profound religious change. Since the encounter with the land is the theme of the next chapter, here I focus primarily on these latter, particular moments of self-transformation.

These moments of religious insight are explored in terms of what Simon Coleman has called "continuous conversion"; namely, a perspective that posits "conversion" more as an ongoing process in which the self moves towards religious conviction than as a spontaneous, one-time event (2003). I wish to suggest that, for the volunteers, the realization of Israel's spiritual significance constitutes a central moment in that process. As a consequence of these narrative performances, not only self-transformation is achieved but also an increased commitment to Israel as a religious symbol.

\section{Realizing Israel's Spiritual Significance}

As we saw in Chapter Two, the connection between twentieth-century Jewish immigration to Palestine and Christian eschatological narratives has a long history in the Protestant imagination. The Christian ministries in Jerusalem rest firmly on this restorationist history and the volunteers have an awareness of it to varying degrees. Yet in many of the volunteers' narratives there are specific and clearly identifiable moments in which Israel's spiritual significance is realized that are often recounted as sudden, sometimes even unexpected, moments of conceptual change. In Hanna's words:

And then the biblical prophecies came to light as I was reading. And it was as if someone turned a lightbulb on in my head and all of a sudden what I'd read since childhood and never understood, all of a sudden 
I realized that this is Israel, this is God's people and He's bringing them from all four corners of the earth.

For Hanna this moment happened before she had visited Israel; it occurred during her period of preparation for the journey, mentioned above. After receiving the calling, she started to do what she calls "research" in order to understand more exactly what God wanted her to do in Israel.

And it was only during those months in [mentions a place] — which were invaluable to me-because I got to really research Israel and really ask questions: "Why am I being brought here? What's it all about? Who are Israel? Who are this people? Are they the people of the Bible?"

It is during this process that the Bible suddenly opens up to her, and lets her understand the importance of Israel, not only in the Scriptures but also in sacred history. For other volunteers, this moment of religious insight is closely related to the first time that they visit the land, often as participants of a Christian tour group. For Marcus, one of the younger European volunteers, it came when he visited a friend who was volunteering for one of the ministries in Jerusalem.

My relation to Israel, the catalyst really for me coming here was when I visited ... a friend who was also working for [the Christian ministry in Jerusalem] at the time. ... He was volunteering here and I came for his final week. ... It just really struck me: the place, the people, and just the importance that Israel and the people had in the Bible. And even though I was only here a week, so much happened and it was just, it was at that point that I just realized that I want to come back again at some point. It's almost like it just captured my heart. And I just left feeling ... almost spiritually drunk from the whole experience. I mean it just stayed with me for so long. I couldn't really get it out of my system, it just sort of seeped into everything I was doing back home. I would see things that had a connection to Israel, whether it was signs or things people said. So I just knew at some point I was going to come back.

For Marcus, as well as for Hanna, this experience of insight had profound effects on the religious self. Hanna describes how it made it possible for her to understand what she had read in the Bible since childhood, things she had not been able to understand before. Marcus felt "spiritually drunk" he says, and the intoxication stayed in his "system" after the journey and "seeped into everything [he] was doing back home". For both Hanna and Jacob these moments 
are narrated as sudden and spontaneous acts of religious change. Other volunteers described it as a slower process that involves the calling, individual Bible studies, prayer, and encounters with significant others such as Messianic Jews, Evangelical preachers, or university teachers. But biographical particularities aside, virtually all volunteers describe the realization of Israel's spiritual significance as part of a thoroughgoing religious change that had a major impact on their understanding of the world, the biblical text, and their own religious identities.

In her ethnography of American pilgrims to Israel Hillary Kaell (2014) describes how thoughts about transformation structure the pilgrim's encounter with the land. Prospective travelers, she writes, often encounter the trope of transformation, even prior to their trips, through the products of the tourism industry, and through conversations with other people who have already made the journey. Travelers even learn to expect transformative experiences in the land, experiences that will forever change how they view the Bible, and that will make their relationship with God more intimate (161-163). This certainly suggests that transformation is a well-established cultural trope among Evangelicals and other prospective travelers to Israel, so encountering these themes among the volunteers is relatively unsurprising. There are many similarities between the volunteers' stories and Kaell's account of American pilgrims but there is also one important difference: among the volunteers, transformation is not only centered on Israel as a location where it is possible to experience the Bible, but on a specific cognitive process of realization that the land and the State of Israel in themselves are religiously significant. This realization transforms Israel from a place in which the biblical stories played out to a religiously loaded concept.

While some volunteers attribute considerable importance to Israel as the historical "land of the Bible", to knowledge about the historical and geographical context of the biblical stories, and to the mimetic practice of "walking where Jesus walked", the main transformative experience is often connected to the realization of contemporary Israel's religious significance. As mentioned above, this experience is narrated as a conceptual change, or as the adoption of a partly new symbolic system which significantly alters the way they view the world, themselves, and the relationship between spiritual and material realities. Hanna's use of visual metaphors, which is also reflected in several other interviews, is highly illustrative of how this experience is generally understood. Realizing Israel's spiritual importance is a change of perspective; it is about suddenly seeing things differently. Meanwhile, people who do not share the volunteers' understanding of Israel are often understood to be subject to a "spiritual blindness", as Hanna puts it. Perhaps the most direct description of 
this understanding comes in an interview with David Parsons, the media director at the ICEJ, when he compares the difference between various religious understandings of Israel in terms of an optical illusion.

Now even the gospel, Paul says it's veiled. People's understanding[s] are veiled to the gospel and to the Jews it's a stumbling block ... But for those of us who have seen the mercy of God in it and understand, it's a love story ... And I think Israel in a way, it's a mystery as well in the Bible ... That's what Paul's talking about. ${ }^{14}$ I don't want you to be ignorant of this mystery. It's the mystery of Israel's enduring election, even after the cross ... And once you see it, you see it everywhere. And it's like that illusion that, you know, you've got to look at from this angle and all of a sudden you see the face of the old woman looking this way instead of the, you know. It's one of these double [pictures] where it looks like a, you know, a guy in a cloak, but if you see it this way it's an old woman with a broom or something. And what you see there, you know, it's easy—-there it is, there it is.

By implication, the knowledge about Israel that the volunteers have discovered is a knowledge that is "veiled", and it takes the guidance of the Holy Spirit to discover contemporary Israel in the biblical texts. In Parsons' understanding, "seeing Israel" equals the process of discovering a second picture in a consciously multi-layered painting. It should be noted that sensory, visual metaphors for spiritual knowledge (light/dark, sight/blindness) commonly occur throughout both the Hebrew and the Christian Bible, particularly in the gospel of John (Stovell 2012), and as such might be considered a cultural trope in Evangelical Biblicism. What is significant here, however, is how this biblical metaphornormally associated with the "new life in Christ" among Christians—is applied instead to the realization of Israel's spiritual significance. It describes a form of knowledge that was previously hidden but is now unlocked through the collaboration of divine agency and an open and willing human subject.

It is of course difficult to know how much these narratives of sudden religious change reflect past biographical events, and to what extent they are infused with present concerns, emotions, understandings, and priorities in the moment that they are told. The "authenticity" of narrative accounts is to some extent always beyond ethnographic knowledge. Yet, with the perspective that was delineated above and which approaches conversion narratives as ritual events, it might be expected that some parts of the past experiences of religious 
change are also visible in the narrative performances themselves. While not all the coming-to-Israel stories exhibit ritual-like characteristics to an equal degree - and differences here, I believe, might be attributable to methodological choices, the interview situations, and to differences between individual storytellers - some of the stories do illustrate the dynamics described by Stromberg. This is exemplified by a return to Ruth's story.

\section{Becoming Ruth}

We left Ruth's story when she had experienced a confirmation of her calling to Israel that was mediated by an unnamed man in the shuvi incident. She now knew that she was meant to return to Israel, and that she was called to work with the Jewish people there. However, what Ruth called her "identity crisis" - the ambivalence that she felt towards her identity as a Christianand which she reenacted throughout her narrative, was not entirely solved by the incident. In her story, God called her back in spite of her sense of ambivalence and confusion; she was certain about the calling, but not about her own identity. However, before closing the narrative, Ruth returned to the question of her conflicted identity. The way she tells it, her identity crisis was solved through what Stromberg describes as the reframing of an emotional conflict in "canonical language", a narrative operation which he sees as a central aspect of the transformative function of conversion narratives $(1993,3)$. Emotional conflict is not necessarily resolved by linking personal experience to a symbolic system, but it can be placed within a framework where it no longer causes the same friction as it did before (1993, 108). In Ruth's case, as for most Evangelical Christians, this symbolic system is conditioned by the Bible. But at the same time it is also a particular form of Evangelical Christianity in which a symbolic role for Israel and the Jewish people has been developed; the problem that she has found difficult to solve is her identity in terms of the particular relationship between Christians and Jews. In Ruth's narrative the pivotal moment comes in a sermon by a messianic speaker that Ruth heard while still in the US, prior to her return to Israel. In his speech—and here reported speech is again used with, I believe, similar implications as above-contemporary Jewish Israelis are identified as the biblical character "Naomi". They have returned to their land, he says, in "bitterness", a bitterness arising from all the terrible things that they have suffered throughout history.

And he said, "I know that many of my Jewish brothers and sisters won't agree with me, but I really believe that what we need is a Ruth to come alongside of us and help, you know, just like Ruth came alongside of Naomi and she was a help to her and a blessing to her. We also need our Christian 
brothers and sisters to do that for us today." If I told you I sobbed, I'm sure you won't be surprised seeing me now [weeping]. But it was like all of a sudden I knew: "Wow! I don't need to go to Israel and, try and be something I'm not." Actually what this people [Jewish Israelis] need, they need to see Christians who are Christians, who aren't ashamed to call themselves Christians, who are not having the same message or doing the same [as] throughout history. And it's not going to be an easy place to stand in because so many, you know, are going to see us through a certain lens. But, ... basically the Lord needs some people, ... some Christians who will come and be a blessing to this people and show a different face of the Messiah, because they can't see the Messiah through the glass that we've shown them, or through the way that we've shown Him throughout history. Ok, so that was my purpose then, and it helped me sort out this whole thing of, you know, why, why would I come? What would be my ... And as far as my identity, God called me as a Christian, I'm supposed to be just that, you know.

The question that had troubled her ever since learning about the role of Christianity in the history of anti-Semitism, that created the "identity crisis" during her first year in Israel, and that made the year in North America so conflicted, found closure by virtue of a typological identification with a biblical character. Susan Harding argues persuasively that born again speech often relies on "figural" or "typological" connections between biblical narratives and personal life stories. A common feature of such narrative constructions is how real life events, characters, and identities are pre-figured by the biblical stories and receive their meaning in relation to interpretations of those stories $(2000,55)$. In the case here, this is the same process that Stromberg identifies as the reframing of emotional conflict by the speakers' adoption of canonical language, and which he argues is a central aspect of both personal transformation and increasing commitment to the "new" symbolic system. The biblical narrative about Ruth and Naomi provides a way for Ruth to harmonize her calling, her strong emotional attachment to Israel, and her own Christian identity. By identifying with the biblical Ruth-in fact, by understanding her own identity in terms of biblical narrative and the connected symbolic system-Ruth feels she can be a "Christian" again. But this narrative operation does not simply take a pre-existing symbolic system and attach it to personal experience; it also re-calibrates the symbolic system in the process. Personal transformation by narrative performance is in part also a transformation of the symbolic system in which personal experience is re-interpreted. Ruth is again called to be a "Christian", but it is a new type of 
"Christian", one that is notably different from those whom "Naomi" has historically encountered. Thus the meaning of "Christian" is fine-tuned by this narrative in relation to the role of the biblical Ruth as friend and supporter of the biblical Naomi: in other words, the relationship between Christians and Jews. The divine calling is directed to this recalibrated Christian identity, not to the old one that Ruth had found to be in conflict with her emotional attachment for Israel. It is by becoming this new, transformed type of Christian that Ruth's conflicted identity is harmonized. Narratively speaking, by becoming Ruth her conflicted identity is made whole.

\section{Continuous Conversion_Faith Walk}

It should be clear from the examples and analysis that the volunteers would object to a description of their religious interest in Israel as something that could be separated from their identity as born-again Christians. While most would not say that understanding Israel in the way they do is a fundamental doctrine comparable to Jesus' salvific work on the cross, or the divine authorship of the Bible, most would agree with Hanna when she argues that not seeing Israel's spiritual significance is a case of "spiritual blindness", and that it represents a severe misinterpretation of the Bible which is attributable to Hellenism's harmful influence on Christianity throughout the centuries (see Chapter Five). Some would go even further and question whether someone who is a believing Christian can fail to see the importance of Israel; if they truly have Jesus in their heart, the Holy Spirit will lead them to understanding.

Despite the religious importance that the volunteers place on seeing Israel in the correct light and how this insight often comes embedded in a rhetoric suggesting a spontaneous and profound religious change, a narrow view of religious conversion that emphasizes a radical break with the past and the adoption of a completely new religious identity is obviously not applicable here. The volunteers were born-again Evangelicals before they became Zionists, and they continue to be so afterwards; in many respects the worldview, the beliefs, and the practices that they had before the spiritual significance of Israel dawned upon them continue to function without any major changes. Christian Zionism here is a process of continuous and increasing identification with the State of Israel, with Jewish symbols and practices, and an integration of these new features into the language and practice of evangelical faith. Joel Robbins has made an important distinction between two main anthropological approaches to religious conversions: the utilitarian approach and the intellectualist approach $(2004,2007)$. While the former perspective explains religious change by emphasizing worldly gain and social mobility, the latter approach, which is what I have emphasized above, "argues that 
converts are attracted to the new religion because it renders meaningful new situations that defy the sense-making capabilities of their traditional ways of understanding the world" $(2004,85)$. Particularly applicable here are approaches that understand conversion not so much as a one-time event but rather as a continuous process of spiritual growth (Austin 1981, Austin-Broos 2003, Coleman 2003, Cucchiari 1988). One such perspective is described by Simon Coleman:

All of these points contribute to a total picture of what I call continuous conversion, in which "continuity" can be understood in a number of related ways. It can imply that movement of the self toward charismatic conviction is an ongoing process, albeit one described by a rhetoric of a spontaneous transformation; it indicates a blurring of the boundaries of identity between religious affiliations; and it suggests that analysis of conversion practices should focus not only on the potential neophyte, but also on broader sets of social relations and ideological representations that include and influence the evangelizing believer.

COLEMAN 2OOob, 17, emphasis in original

Coleman's broader articulation of the conversion concept describes religious change as a process that does not necessarily begin as abruptly as often articulated in conversion narratives, and that does not end once the religious subject becomes, as it were, "saved". Rather, conversion here is understood as an ongoing movement of the self towards increasing religious insight, a deeper faith, and, in the Christian case, a more intimate relationship with Jesus. In other words, "continuous conversion" implies the possibility of increasingly integrating one's own life with the symbols, linguistic practices, rituals, social relationships, and bodily experiences that are provided by the particular form of religion that one is drawn to.

There is, in fact, an Evangelical formulation of the process described by Coleman, one that is frequently employed by the volunteers when they describe their engagement with Israel, and how this engagement has influenced-or "deepened"-their religious commitment. In Evangelical terms this process is recognized as the "faith walk" or "walk with God". Israel is integral to this among the volunteers, both as a religious symbol, and as a place in which it becomes possible to enact the insight about Israel's spiritual significance. For them, volunteering in Israel provides an opportunity to live increasingly by faith, to learn to rely on God, to restructure life patterns, and to grow in understanding about spiritual matters. As we will 
see in more detail in the next chapter, being in Israel is commonly associated with both challenges and blessings; it is a trying experience but also rewarding for those who do it for the right reasons and who learn to rely on God's providence.

I count it very much a blessing to be here, but I don't find my identity in being here. There's a big difference. At one point it looked like I was going to have to return to the States because I didn't have all the money to complete the course [that I was doing in Israel]. But the Lord orchestrated that circumstance and I had to raise several thousand dollars within a week or else I was going to have to return to the States. And I remember being very upset with God. And I'm like, "Lord, I quit my job, I did this and that, and now you're going to send me back to the States and I haven't even completed this course?" The Lord said, spoke to my heart and said: "Where's your identity? Is your identity in being in Jerusalem or is your identity in me? Is your identity in what you're doing or is your identity in who you are in me?" And I had to really look at that. And the Lord said: "If I want to send you back to the West Coast without completing this course, it shouldn't matter to you, your life is not your own." So I had to really come to terms with it that day. I said, "Ok, God, if I get sent back to the West Coast I'll go." The moment I let it go, within a week 2,30o dollars was raised and God showed me that He wanted me to be here in Israel, but He had to deal with that identity first.

God, in Jacob's discourse, contrasts "identity in me" versus "identity in Israel" and makes it clear that Jacob's place in Israel is completely dependent on God and that Israel is subordinate in the faith walk. Reflections of this conceptualization of his engagement with Israel are visible in several of the volunteer's narratives, and many of them frequently emphasize that in the end it is the individual relationship to God that matters- "not Israel". In the quote below, Marcus describes how he came to reevaluate his own work in Israel after listening to a Messianic preacher:

And he was telling us that the reason we're here is because God wants to do a work in us. It's specifically for our relationship with him. And when he said that, it really struck me deeply. It then made me reevaluate why I was here [in Israel], because I think for a lot of us we come here thinking, "Yes, we're coming to bless the Jewish people." And that's great and, and that's what we're trying to do. But I think more important than that, it's about our own walk with God. And it's from being here that I feel like my, 
that my faith has increased a lot. And I think my walk has improved a lot with the Lord.

In terms of religious change, there is a certain amount of tension between the strong narrative emphasis on the realization of Israel's spiritual significance and the enactment of this insight through the volunteer work, and the subordination of Israel to a secondary role in the faith walk. On the one hand, the conceptual change described in the coming-to-Israel stories is narrated as a radical rupture from the past, and the new knowledge about Israel is understood as both fundamental and radically transformative. Narratively speaking, Israel is a key concept that drives the self-transformation in these stories. On the other hand, Israel, as a place, is relegated to an instrumental role in the walk with God, one which may never become more important than the walk in itself. For Jacob, this tension is articulated in terms of "identity-in-Israel" or "identity-inGod" where the former represents a distortion, or at least a misguided faith in something that should be secondary.

These tensions are rarely, if ever completely resolved in the volunteers' stories. As we will also see in the next chapter, this type of negotiation of the role of Israel and the meaning attributed to it is a commonly recurring theme. The discursive practices concerning Israel that situate it as unique, as a mediator of self-transformation and divine intent, that locate Israel as a religious symbol through which one can experience and interact with divine realities, do not always find support in the broader theological tradition to which the volunteers also belong. In these cases, the volunteers often compromise their own talk about Israel by drawing on these broader traditions. In a sense, these negotiations might be seen as representing an ongoing process of finding theological space for a religiosity that engages Israel as a religious symbol, a material object that can mediate divine presence, uniquely and fundamentally. In finding that space, Evangelical Zionists need to negotiate broader Protestant tradition and its emphasis on immateriality, interiority, and iconoclasm. The discursive practices, or lived religiosity, seem to be the engine in this process; broader theological traditions will have to follow.

\section{Conclusions}

The coming-to-Israel stories of the volunteers in Jerusalem engage with two narrative genres that have played a big role in the articulation of Christian identities historically: the calling narrative and the conversion narrative. In their respective stories the dialectical formulation of agency, the production 
of meaning through its opposite, and the task of properly locating divine intention are central preoccupations. However, while the stories formally draw heavily on established Christian tropes, they also introduce a new element by articulating the realization of Israel's spiritual significance as a central moment in the process self-transformation. In these stories, the narrative space traditionally occupied by the encounter with Christ is here occupied by the encounter with the State of Israel. Such transformation, however, should not be seen as a definite rupture from the past but rather as a part of a continuous process of increasing religious commitment.

I have here emphasized the role of Israel as a symbolic object in this process. It is through realizing that God is continuing to work with Israel that one also realizes how God works with the self. To some extent, the emphasis placed on Israel represents an important recalibration of Evangelical symbolic systems and what it means to be an Evangelical Christian. In that sense, these narratives represent both continuity and discontinuity with Evangelical forms of religion more broadly. In terms of the discussion here, these Evangelical narratives can be seen as reflecting an ambition to find theological space for a religious symbol not traditionally included in these formulations of faith. It is precisely in the tension between continuity and discontinuity that a sense of self-transformation emerges; the symbolic role of Israel is a new articulation of old Evangelical truths about the relationship between God, the world, and the self. 